\title{
Penerapan Model Strut-and-Tie untuk Memprediksi Kekuatan Geser Sambungan Balok-Kolom Interior Gedung PPIIG UPR
}

\author{
Ari Kusmawan ${ }^{1, *}$,Fransisco Happy Riadi Haputra Baru ${ }^{1}$, Lilik Hermawan ${ }^{1}$ \\ Jurusan Teknik Sipil, Universitas Palangka Raya, Palangka Raya ${ }^{1}$ \\ Koresponden*, Email: ari.kusmawan.96@gmail.com
}

\begin{tabular}{|c|c|c|}
\hline & Info Artikel & Abstract \\
\hline Diajukan & 02 Juni 2021 & The beam-column conncetion under lateral load is an area that often experiences collapse in \\
\hline Diperbaiki & 07 Juli 2021 & the form of shear failure, therefore a fairly accurate method is needed to calculate the shear \\
\hline Disetujui & 10 Juli 2021 & $\begin{array}{l}\text { capacity in this area. The softened Strut-and-Tie Model (STM) method was proposed to } \\
\text { calculate the nominal shear force of the PPIIG UPR building beam-column joint. The analysis } \\
\text { results showed that the shear force on the core of the beam-column connection under lateral }\end{array}$ \\
\hline \multicolumn{2}{|c|}{$\begin{array}{l}\text { Keywords: beam-column connection, } \\
\text { calculate the shear capacity, softened strut- } \\
\text { and-tie model, joint shear strength. }\end{array}$} & $\begin{array}{l}\text { load was } 1480,28 \mathrm{kN} \text { which was greater than the shear capacity of the beam-column connection } \\
996,58 \mathrm{kN} \text {, therefore the amount of shear reinforcement plus the shear capacity of the beam- } \\
\text { column connection that met the requirements in the connection area was } 3 D 12-100 \mathrm{~mm} \text { with } \\
\text { a total shear strength was } 1706,96 \mathrm{kN} \text {. }\end{array}$ \\
\hline
\end{tabular}

Abstrak

Sambungan balok-kolom di bawah beban lateral adalah daerah yang sering mengalami keruntuhan berupa kegagalan geser, oleh karena itu dibutuhkan suatu metode yang cukup akurat untuk menghitung kapasitas geser pada daerah ini. Metode softened Strut-and-Tie Model (STM) diusulkan untuk menghitung gaya geser nominal sambungan balok-kolom gedung PPIIG UPR. Hasil analisis menunjukkan bahwa gaya geser pada inti sambungan balok-kolom di bawah beban lateral adalah $1480,28 \mathrm{kN}$ lebih besar dari kapasitas geser sambungan balok-kolom 996,58 $\mathrm{kN}$, sehingga jumlah tulangan geser ditambah kapasitas geser sambungan balok-kolom yang memenuhi persyaratan pada daerah sambungan

Kata kunci: sambungan balok-kolom, menghitung kapasitas geser, model strutand-tie, kuat geser sambungan adalah 3D12-100 mm dengan kuat geser total sebesar $1706,96 \mathrm{kN}$.

\section{Pendahuluan}

Sambungan balok-kolom dalam struktur rangka beton bertulang adalah daerah diskontinuitas yang mengalami gangguan aliran gaya yang berhubungan dengan distribusi regangan nonlinier [1]. Oleh karena itu, desain konvensional tidak dapat diterapkan di daerah sambungan dan metode yang diterapkan berdasarkan model fisik yang realistis dan mudah dipahami harus diterapkan pada daerah ini. Konsep ini memungkinkan penggunaan metode Strut-and-Tie Model (STM) untuk analisis beton bertulang struktural pada daerah tersebut.

Penggunaan metode Strut-and-Tie untuk menganalisis perilaku sambungan balok-kolom di bawah beban seismik telah dilakukan dari waktu-ke-waktu baik pada beton bertulang biasa maupun pada beton pracetak. Hwang dan Lee [2], [3] mengusulkan metode yang disebut Softened Strutand-Tie Model yang digunakan untuk memprediksi kekuatan geser sambungan balok-kolom interior dan eksterior terhadap beban seismik dilakukan, hasil menunjukkan bahwa model yang diusulkan mampu memprediksi kekuatan geser sambungan dengan hasil yang memuaskan. Perilaku sendi plastis menggunakan metode Strut-and-Tie juga diteliti oleh Hong dan Lee [4], dan Hwang dan Park [5]. Hasil menunjukkan model yang diusulkan dapat digunakan sebagai alat yang rasional untuk evaluasi sambungan yang ada dan untuk desain tidak hanya untuk zona kegempaan tinggi tetapi juga zona kegempaan rendah atau menengah. Model analitis berdasarkan metode STM untuk memprediksi kekuatan geser sambungan balok-kolom juga diusulkan [6], [7]. Penggunaan model Strut-and-Tie untuk beton struktural di bawah beban dinamis untuk mengembangkan metode optimasi numerik yang andal dan efisien juga dilakukan [8]. Model semi empiris untuk memprediksi kekuatan geser sambungan eksterior di bawah beban seismik menggunakan model Strut-and-Tie juga dilakukan [9].

Model Strut-and-Tie untuk menghitung beban tarik ultimate sambungan beton pracetak juga diusulkan oleh Ong dan Paramasivan [10], hasil penelitian menunjukkan bahwa prediksi menggunakan model yang diusulkan berkorelasi baik dengan data eksperimen.

Berdasarkan uraian diatas, penggunaan metode Strutand-Tie untuk menganalisis perilaku sambungan balokkolom dan untuk memprediksi kekuatan geser di bawah beban lateral memberikan hasil analisis yang cukup memuaskan sehingga dapat diterapkan pada perencanaan sambungan. 


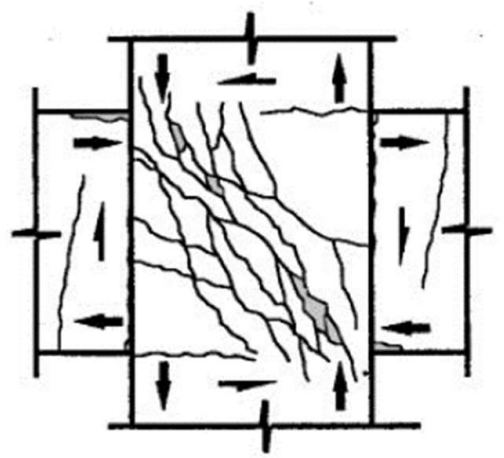

Gambar 1. Daerah Diskontinuitas Sambungungan BalokKolom Beton Bertulang dalam Kegagalan Tekan Diagonal [3]

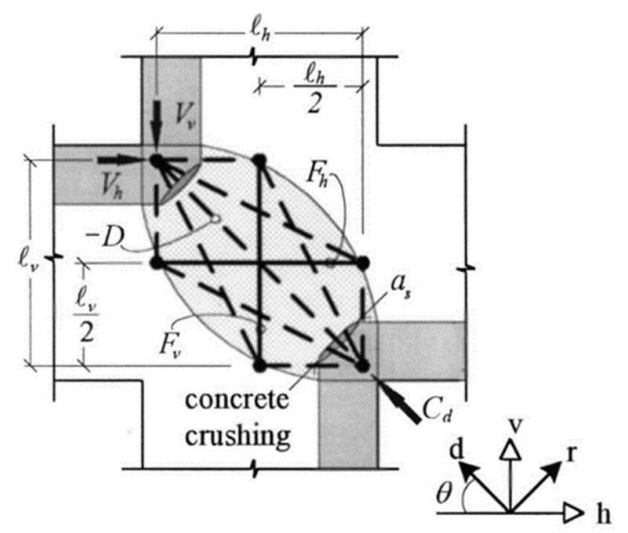

Gambar 2. Model Strut-and-Tie Sambungan Balok-Kolom Interior [3]

\section{Permodelan Strut-and-Tie}

Setelah dilakukan perhitungan perancangan tulangan longitudinal, torsi dan geser balok dan tulangan longitudinal kolom, daerah sambungan balok-kolom interior dimodelkan untuk mengetahui gaya geser yang bekerja pada beban lateral dan gaya geser yang mampu ditahan oleh sambungan balokkolom yang didesain.

\section{Gaya Geser yang Bekerja pada Sambungan Balok-} Kolom Interior

Gaya geser yang bekerja pada sambungan balok-kolom interior di bawah pembebanan lateral Gambar 3 dapat dihitung dengan persamaan 1 [4].

$V_{j h}=T_{b 2}+C_{b 1}-V_{c}$

dimana, $V_{j h}$ adalah gaya geser horizontal pada joint; $T_{b 2}$ adalah gaya tarik tulangan balok pada sisi kanan kolom; $C_{b l}$ adalah gaya tekan balok tekan lentur pada muka kiri kolom; dan $V c$ adalah gaya geser kolom di atas sambungan.

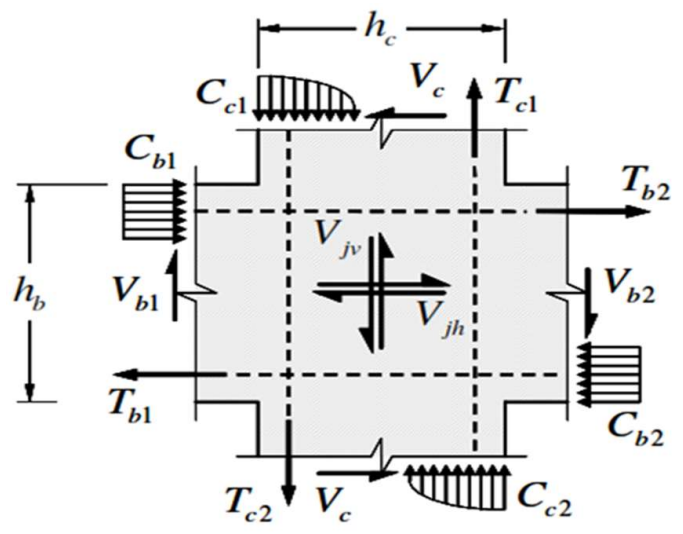

Gambar 3. Gaya-Gaya yang Bekerja pada Sambungan Balok Kolom Interior [4]

Persamaan (1) dapat diuraikan menjadi persamaan 2.

$V_{j h}=A_{s 2} . f_{y}+A_{s 1} \cdot f_{y}-\frac{M_{p r}{ }^{+}+M_{p r}{ }^{-}}{h}$

dimana, $A_{s}$ adalah luas tulangan balok; $f_{y}$ adalah kuat tarik baja tulangan; $M_{p r}$ adalah momen kapasitas ujung balok; dan $h$ adalah tinggi bersih kolom.

Persamaan (2) dikembangkan dengan mengasumsikan tegangan pada tulangan tarik lentur joint balok-kolom Sistem Rangka Pemikul Momen Khusus sebesar 1,25 $f_{y}$ sesuai dengan Pasal 18.8.2 SNI 2847-2019 [11], sehingga menjadi:

$V_{j h}=A_{s 2} \cdot 1,25 f_{y}+A_{s 1} \cdot 1,25 f_{y}-\frac{M_{p r}^{+}+M_{p r}{ }^{-}}{h}$

\section{Geometri Model Strut-and-Tie}

Bidang tegangan untuk sambungan balok-kolom interior seperti yang ditunjukkan pada Gambar 4 menggunakan persaaman 4 dan 5 [4].

$a_{b}=\frac{A_{s} \cdot f_{y}}{0,85 \cdot b_{b} \cdot f_{c}{ }^{\prime}}$

$a_{c}=\left(0,25+\frac{N}{h_{c} b_{c} \cdot f_{c}^{\prime}}\right) \cdot h_{c}$

dimana, $a_{b}$ adalah kedalaman zona tekan balok dan $a_{c}$ adalah kedalaman zona tekan kolom.

Setelah menentukan zona tekan balok dan kolom sudut inklinasi atau sudut kemiringan tekan diagonal terhadap sumbu horizontal berdasarkan Gambar 2 menggunakan persamaan $6[3]$.

$\theta=\tan ^{-1} \times\left(l_{v} / l_{h}\right)$ 
dimana, $\theta$ adalah sudut inklinasi; $l_{v}$ adalah jarak titik pusat tulangan longitudinal balok; dan $l_{h}$ adalah jarak titik pusat tulangan longitudinal kolom.

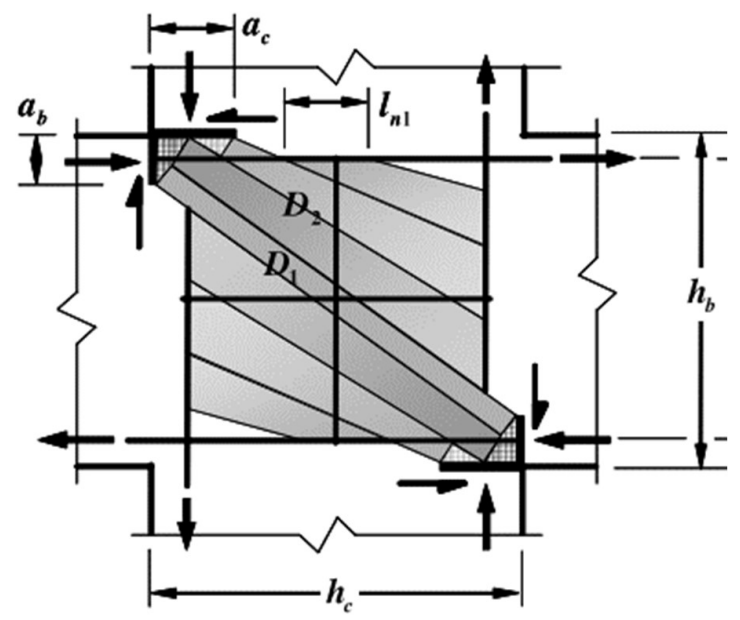

Gambar 4. Bidang Tegangan Sambungan Balok Kolom Interior [4]

Luas diagonal Strut dapat dihitung dengan persaman 7, 8, dan 9 [3].

$$
\begin{aligned}
& A_{s t r}=a_{s} \cdot b_{s} \\
& a_{s}=\sqrt{a_{b}^{2}+a_{c}^{2}} \\
& b_{s}=\sqrt{\left(l_{v}{ }^{\prime}\right)^{2}+\left(l_{h}{ }^{\prime}\right)^{2}}
\end{aligned}
$$

dimana, $A_{s t r}$ adalah luas efektif diagonal Strut; $a_{s}$ kedalaman zona tekan diagonal; dan $b_{s}$ adalah lebar diagonal Strut.

Nilai $\mathrm{K}$ indeks STM dapat dihitung dengan persamaan 10-16 [3].

$K=K_{h}+K_{v}-1$

$K_{h}=1+\left(\overline{k_{h}}-1\right) \cdot \frac{F_{h}}{\overline{F_{h}}} \leq \overline{k_{h}}$

$K_{v}=1+\left(\overline{k_{v}}-1\right) \cdot \frac{F_{v}}{\overline{F_{v}}} \leq \overline{k_{v}}$

$F_{h}=A_{s b} . f_{y}$

$F_{v}=A_{s c} \cdot f_{y}$

$\overline{F_{h}}=\gamma_{h} \cdot \overline{k_{h}} \cdot \zeta \cdot f_{c}{ }^{\prime} \cdot A_{s t r} \cdot \cos \theta$

$\overline{F_{v}}=\gamma_{v} \cdot \overline{k_{v}} \cdot \zeta \cdot f_{c}{ }^{\prime} \cdot A_{s t r} \cdot \sin \theta$

dimana, $K$ adalah indeks Strut-and-Tie; $K_{h}$ adalah horizontal Tie indeks; $K_{v}$ adalah vertikal Tie indeks; $F_{h}$ adalah jumlah gaya horizontal; $F_{v}$ adalah jumlah gaya vertikal; $\overline{F_{h}}$ adalah jumlah gaya horizontal Tie yang seimbang; dan $\overline{F_{V}}$ adalah jumlah gaya vertikal Tie yang seimbang.

Untuk menyelesaikan persamaan (13) dan persamaan (14) dibutuhkan koefisien pelunakan beton $(\zeta)$, distribusi gaya horizontal dan vertikal $\left(\gamma_{\mathrm{h}}\right.$ dan $\left.\gamma_{\mathrm{v}}\right)$, maka bisa menggunakan persamaan 17-19 [3].

$$
\begin{aligned}
& \zeta=\frac{3,35}{\sqrt{f_{c}{ }^{\prime}}} \leq 0,52 \\
& \gamma_{h}=(2 \tan \theta-1) / 3 \\
& \gamma_{v}=(2 \cot \theta-1) / 3
\end{aligned}
$$

dimana, $\zeta$ adalah koefisien pelunakan beton; dan $f_{c}$ ' adalah kuat tekan silinder beton (MPa).

\section{Gaya Geser Nominal Sambungan}

Setelah menghitung indeks Strut-and-Tie dan koefisien pelunakan beton, maka kuat geser nominal sambungan balok-kolom dapat diketahui dengan persamaan 20 dan 21 [3].

$C_{d n}=K . \zeta . f_{c}{ }^{\prime} \cdot A_{s t r}$

$\phi C_{d n}=\phi C_{d n} \cos \theta$

dimana, $C_{d n}$ adalah kuat geser nominal sambungan balokkolom; dan $\phi$ adalah faktor reduksi kekuatan sambungan sebesar 0.85 .

\section{Hasil dan Pembahasan}

Analisis dan permodelan Strut-and-Tie dilakukan pada sambungan balok-kolom interior gedung Pusat Pengembangan Iptek dan Inovasi Gambut Universitas Palangka Raya (PPIIG UPR) dengan sketsa sambungan ditampilkan pada Gambar 9. Analisis dan permodelan gedung PPIIG UPR menggunakan SAP2000 juga dilakukan guna mendapatkan gaya-gaya dalam berupa momen, torsi, dan gaya geser pada balok serta gaya aksial pada kolom. Permodelan struktur gedung PPIIG UPR menggunakan software SAP2000 disajikan dalam Gambar 5 dan sambungan yang ditinjau ditanpilkan pada Gambar 6 dan Gambar 7.

Setelah dilakukan analisis menggunakan bantuan Software SAP2000, hasil perhitungan tulangan longitudinal balok dan kolom pada daerah sambungan balok-kolom disajikan pada Tabel 1.

Tabel 1. Rekapitulasi Tulangan Longitudinal Balok dan Kolom Pada Daerah Sambungan

\begin{tabular}{lccc}
\hline $\begin{array}{c}\text { Elemen } \\
\text { Struktur }\end{array}$ & $\begin{array}{c}\text { Dimensi } \\
(\mathrm{mm})\end{array}$ & $\begin{array}{c}\text { Tulangan } \\
\text { Tumpuan }\end{array}$ & $\begin{array}{c}\text { Luas Tulangan } \\
(\mathrm{mm})\end{array}$ \\
\hline Balok B5 $8 \mathrm{~m}$ & $300 \times 800$ & 9D19 & 2551,75 \\
Balok B5 4 m & $300 \times 800$ & 4D19 & 1134,11 \\
Kolom K2 & $600 \times 600$ & 20D25 & 10134,14 \\
\hline
\end{tabular}


Permodelan Strut-and-Tie sambungan balok-kolom interior gedung PPIIG UPR diilustrasikan pada Gambar 8, dengan perhitungan kekuatan geser sambungan sebagai berikut:

1. Gaya geser pada inti sambungan balok-kolom $\left(V_{j h}\right)$

$$
\begin{aligned}
V_{j h}= & A_{s 2} .1,25 f_{y}+A_{s 1} .1,25 f_{y}-\frac{M_{p r}{ }^{+}+M_{p r}{ }^{-}}{h} \\
V_{j h}= & (2551,75 \times(1,25 \times 400)+(1134,11 \times(1,25 \times 400) \\
& -\frac{390,85+769,62}{3,2} \\
= & 1275.8793+567.0575-362.64939 \\
= & 1480.2874 \mathrm{kN}
\end{aligned}
$$

2. Menghitung daerah tekan $\left(a_{b}, a_{c}\right)$

$$
\begin{aligned}
a_{b} & =\frac{A_{s} \cdot f_{y}}{0,85 \cdot b_{b} \cdot f_{c}^{\prime}}=\frac{1134,11 \times 400}{0,85 \times 400 \times 21,7}=81,98 \mathrm{~mm} \\
a_{c} & =\left(0,25+\frac{N}{h_{c} b_{c} \cdot f_{c}^{\prime}}\right) \cdot h_{c} \\
& =\left(0,25+\frac{5091,13}{(300 \cdot 800) \times 21,7}\right) \times 600=150,39 \mathrm{~mm}
\end{aligned}
$$

3. Luas diagonal strut $\left(A_{s t r}\right)$

$$
\begin{aligned}
a_{s} & =\sqrt{a_{b}^{2}+a_{c}^{2}}=\sqrt{81,98^{2}+150,39^{2}} \\
& =171,28 \mathrm{~mm} \\
A_{s t r} & =a_{s} \cdot \sqrt{l_{v}^{2}+l_{h}^{2}}=171,28 \cdot \sqrt{681^{2}+470,6^{2}} \\
& =141786,67 \mathrm{~mm}^{2}
\end{aligned}
$$

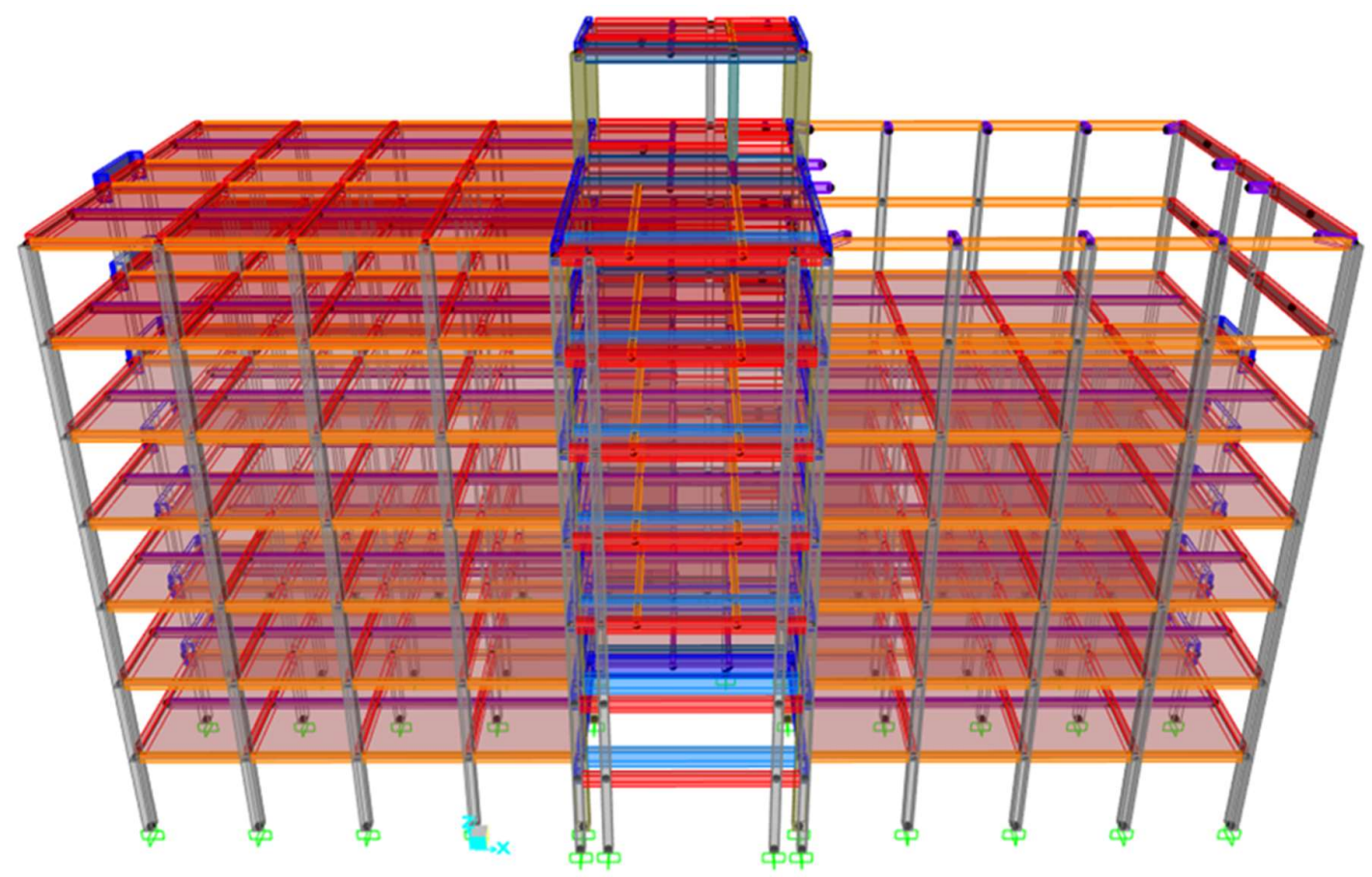

Gambar 5. Permodelan Gedung PPIIG UPR

4. Indeks Strut-and-Tie $(K)$

$\gamma_{\mathrm{h}}=(2 \tan \theta-1) / 3=(2 \tan 55.3539-1) / 3=0.6313$

$\gamma_{\mathrm{v}}=(2 \operatorname{cotan} \theta-1) / 3=(2 \operatorname{cotan} 55.3539-1) / 3=0.1273$

$$
\begin{aligned}
\overline{k_{h}} & =\frac{1}{1-0,2\left(\gamma_{h}+\gamma_{h}{ }^{2}\right)} \\
& =\frac{1}{1-0,2 \times\left(0,6313925+0,6313925^{2}\right)}=1,25946
\end{aligned}
$$

$$
\begin{aligned}
\overline{k_{v}} & =\frac{1}{1-0,2\left(\gamma_{v}+\gamma_{v}{ }^{2}\right)} \\
& =\frac{1}{1-0,2 \times\left(0,1273617+0,1273617^{2}\right)}=1,02956 \\
\zeta & =\frac{3,35}{\sqrt{f_{c}^{\prime}}} \leq 0,52=\frac{3,35}{\sqrt{21,6}}=0,7191>0,52 \\
F_{h} & =A_{s b} \cdot f_{y}=(1134,115+1134,115) \times 400 \\
& =907,29196 \mathrm{kN} \\
F_{v} & =A_{s b} \cdot f_{y}=(3040,2) \times 400=1216,0979 \mathrm{kN}
\end{aligned}
$$




$$
\begin{aligned}
\overline{F_{h}} & =\gamma_{h} \cdot \overline{k_{h}} \cdot \zeta \cdot f c^{\prime} \cdot A_{s t r} \cdot \cos \theta \\
& =0,6313 \times 1,2594 \times 0,52 \times 21,7 \times 141786,67 \times \cos (55,3539) \\
& =723,29927 \mathrm{kN} \\
\overline{F_{v}} & =\gamma_{v} \cdot \overline{k_{v}} \cdot \zeta \cdot f c^{\prime} \cdot A_{s t r} \cdot \sin \theta \\
& =0,1273 \times 1,0295 \times 0,52 \times 21,7 \times 141786,67 \times \sin (55,3539) \\
& =211,13133 \mathrm{kN} \\
K_{h} & =1+\left(\overline{k_{h}}-1\right) \times \frac{F_{h}}{\overline{F_{h}}} \leq \overline{k_{h}} \\
& =1+(1,2594-1) \cdot \frac{907,29196}{723,2993} \leq 1,2595 \\
& =1,3255>1,2595 \rightarrow \text { dipakai } 1,2595
\end{aligned}
$$

$$
\begin{aligned}
& K_{v}=1+\left(\overline{k_{v}}-1\right) \times \frac{F_{v}}{\overline{F_{v}}} \leq \overline{k_{v}} \\
& =1+(1,1231-1) \cdot \frac{1216,0979}{211,1313} \leq 1,0296 \\
& =1,1703>1,0296 \rightarrow 1,0296 \\
& \text { Total indeks }(K): \\
& K=K_{h}+K_{v}-1=1,2595+1,0296-1=1,2890 \\
& \text { 5. Hasil kuat geser nominal sambungan }\left(C_{d n}\right) \\
& C_{d n}=K . \zeta \cdot f_{c}{ }^{\prime} \cdot A_{s t r} \\
& =1,2890 \times 0,52 \times 21,7 \times 141786,6746 \\
& =2062,3411 \mathrm{kN} \\
& \phi C_{d n} \cos \theta=0,85 \times 2062,3411 \times \cos (55,3539) \\
& \quad=996,58 \mathrm{kN}
\end{aligned}
$$

6. Kontrol:

$\phi C_{d n} \cos \theta=996,58 \mathrm{kN}<V_{j h}=1480,28 \mathrm{kN}$ sehingga memerlukan perhitungan tulangan geser.

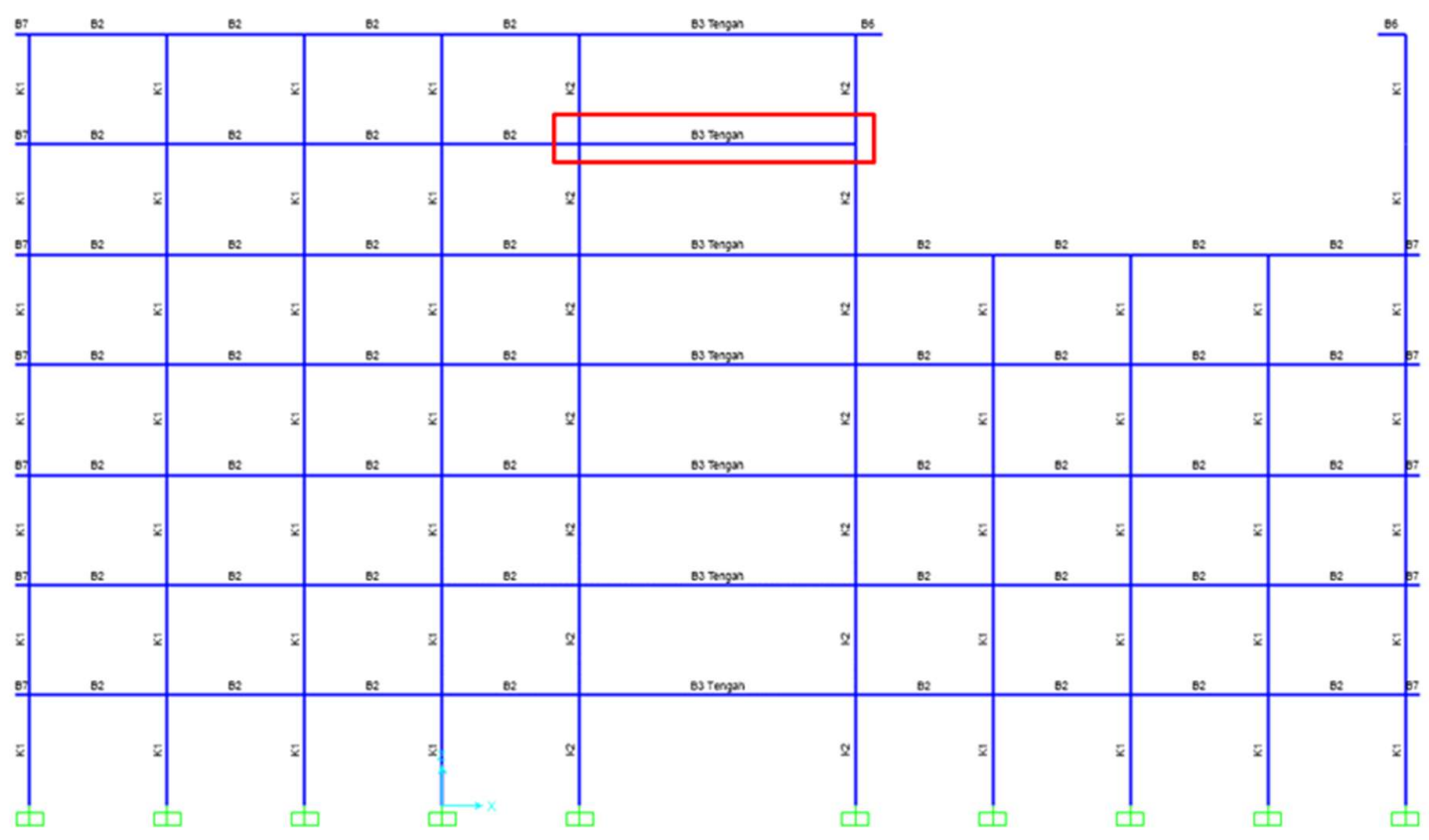

Gambar 6. Sambungan yang ditinjau Arah Memanjang

Karena kuat geser nominal lebih kecil dari gaya geser total pada inti sambungan balok-kolom, sehingga membutuhkan tulangan geser, maka selanjutnya akan dihitung kebutuhan tulangan geser.

7. $V_{i j i n}$ dari sambungan balok-kolom sesuai Pasal 21.7.4 SNI 2847:2013 [12], untuk balok pada ke 4 sisi kolom:

$$
\begin{aligned}
V_{i j i n} & =1,7 \sqrt{f_{c}{ }^{\prime}} A j=1,7 \times \sqrt{21,7} \times(600 \times 600) \\
& =2850,89 \mathrm{kN}
\end{aligned}
$$

8. Periksa gaya geser sambungan:

$$
\begin{aligned}
& V_{j h}=1480,28 \mathrm{kN} \leq V_{i j i n}=2850,89 \mathrm{kN} \\
& V_{j h} \leq V_{i j i n} \rightarrow \text { Memenuhi Persyaratan }
\end{aligned}
$$




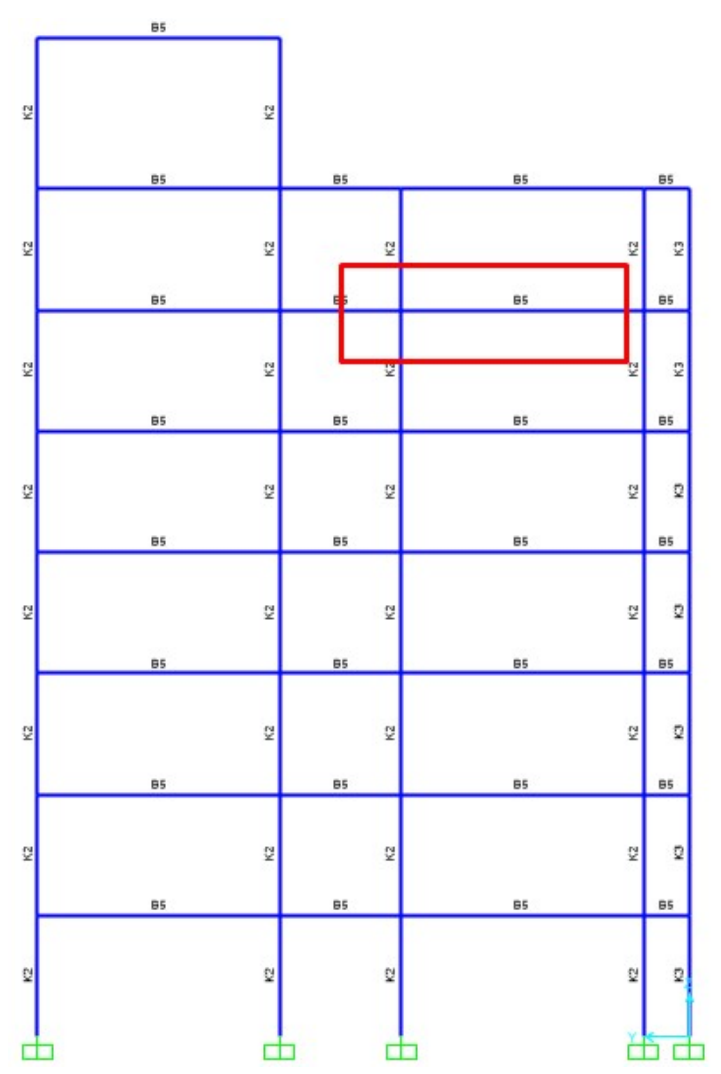

Gambar 7. Sambungan yang ditinjau Arah Melintang

9. Kekuatan geser beton $\left(V_{c}\right)$ sesuai pasal 11.2.1.2 SNI 2847:2013 [12], $V_{c}=0,17\left(1+\frac{N_{u}}{14 A_{g}}\right) \lambda \sqrt{f_{c}{ }^{\prime}} b d$

$$
\begin{aligned}
& =\frac{\left(0,17\left(1+\frac{5091,125 \times 1000}{14 \times(600 \times 600)}\right) \times 1 \times \sqrt{21,7} \times 600 \times 535,3\right)}{1000} \\
& =511,27484 \mathrm{kN}
\end{aligned}
$$

10. Menghitung $V_{s}$

$$
\begin{aligned}
\frac{V_{j h}}{\phi} & =V_{c}+V_{s}+\phi C_{d n} \operatorname{Cos} \theta \\
V_{s} & =\frac{V_{j h}}{\phi}-V_{c}-\phi C_{d n} \operatorname{Cos} \theta \\
& =\frac{1480,2874}{0,75}-511,27484-996,58567 \\
& =465,85603 \mathrm{kN}
\end{aligned}
$$

11. Menghitung luas tulangan geser $\left(A_{v}\right)$ dengan jarak antar tulangan $(S)=100 \mathrm{~mm}$

$$
A_{v}=\frac{V_{s} \times S}{f_{y s} \times d_{v}}=\frac{465,8560 \times 100}{240 \times 535,3}=362,6129 \mathrm{~mm}^{2}
$$

Sehingga digunakan tulangan 3D12 - $100 \mathrm{Av}=339.2920$ $\mathrm{mm}^{2}$ dengan kemampuan gesernya menjadi:

$$
\begin{aligned}
V_{s} & =\frac{A_{v} \times f_{y s} \times d}{S}=\frac{339,2920 \times 240 \times 535,3}{100} \\
& =435,8952 \mathrm{kN}
\end{aligned}
$$

Sehingga:

$\phi\left(V_{c}+V_{s}\right)+\phi C_{d n} \cos \theta=1706,96 \mathrm{kN}>V_{j h}=1480,28 \mathrm{kN}$.

$\phi\left(V_{c}+V_{s}\right)+\phi C_{d n} \cos \theta \geq V_{j h} \rightarrow$ Memenuhi

Berdasarkan hasil perhitungan kekuatan geser sambungan balok-kolom interior Gedung PPIIG UPR menggunakan metode STM, maka detail penulangan sambungan balokkolom diilustrasikan pada Gambar 10.

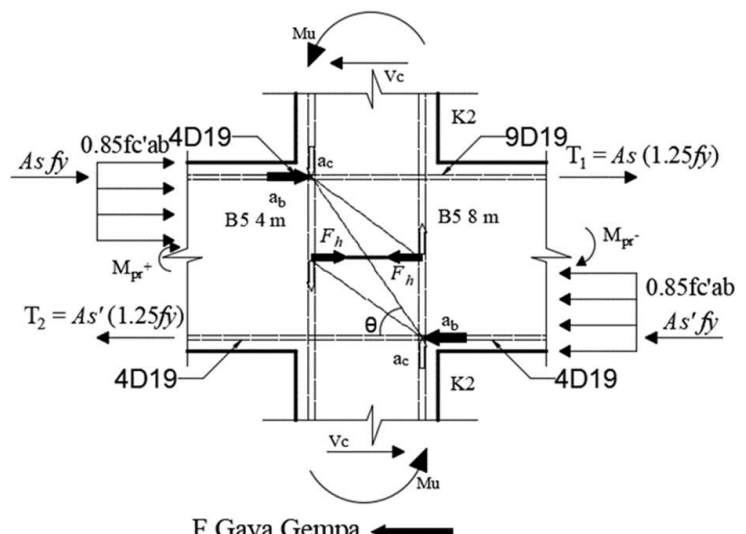

Struktur Bergoyang ke Kiri

Gambar 8. Permodelan Strut-and-Tie Sambungan Balok-Kolom Interior Gedung PPIIG UPR 


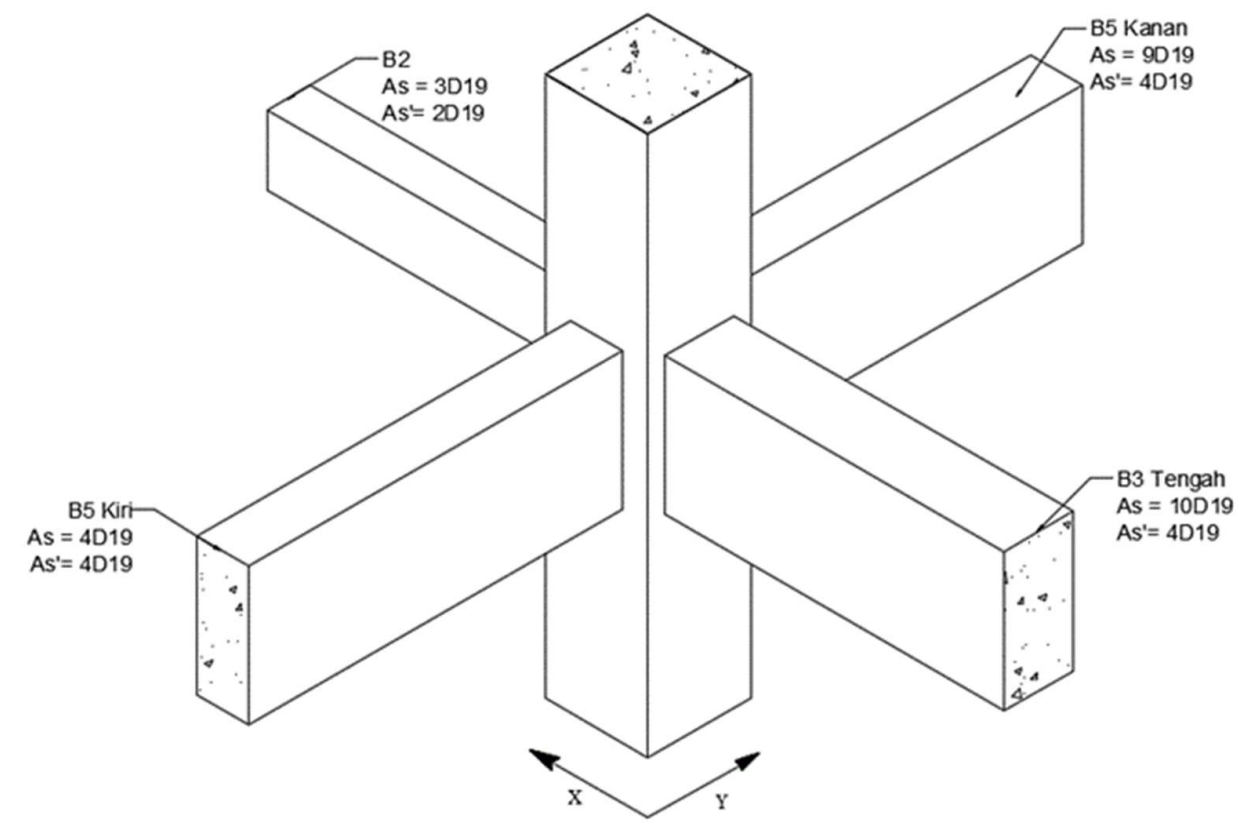

Gambar 9. Sketsa Sambungan yang Didesain

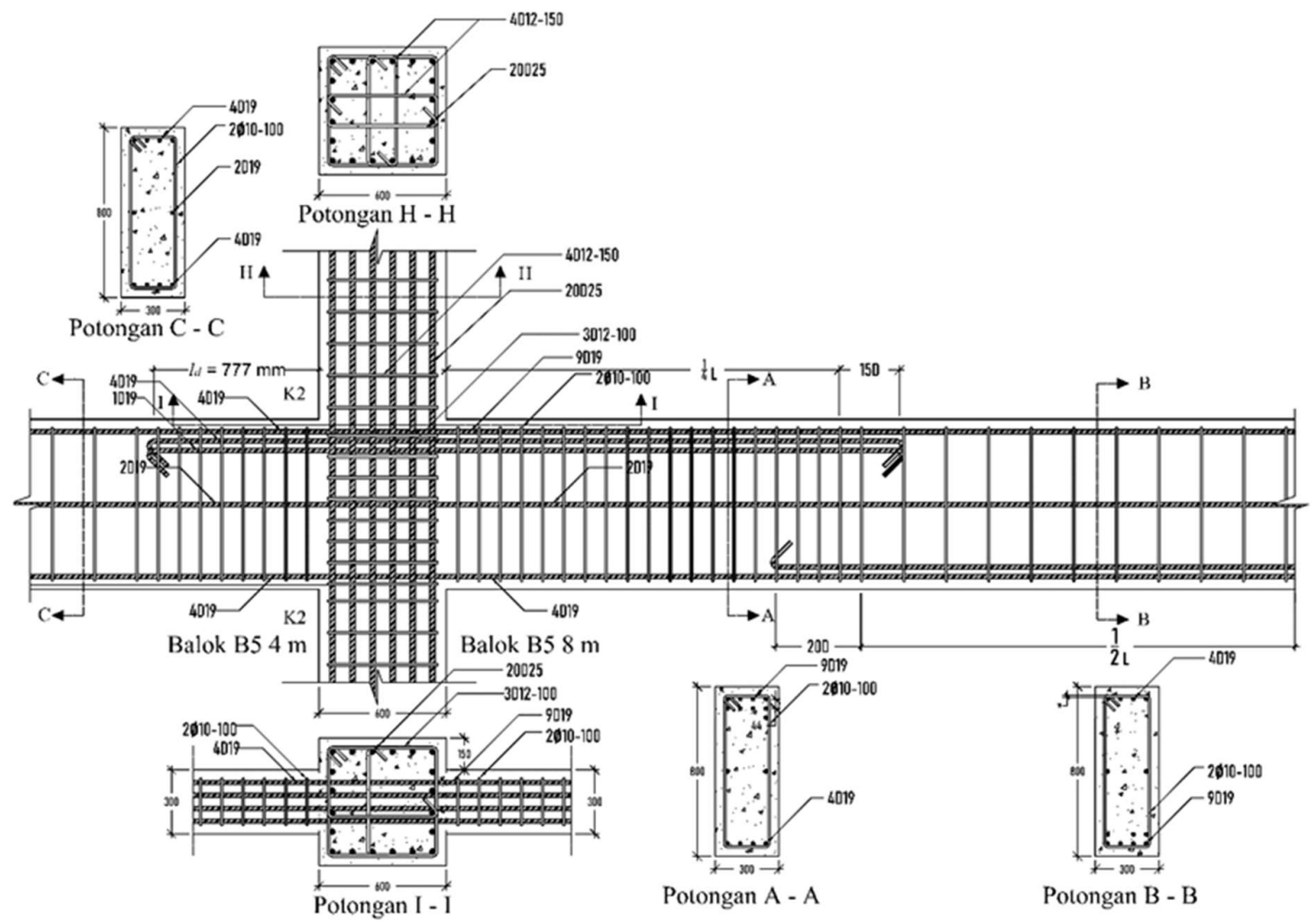

Gambar 10. Detail Dimensi dan Tulangan Geser Sambungan Balok-Kolom Berdasarkan Perhitungan Strut-and-Tie 


\section{Simpulan}

Berdasarkan hasil perhitungan kapasitas geser sambungan balok-kolom gedung PPIIG UPR menggunakan metode Strut-and-Tie maka dapat disimpulkan sebagai berikut:

1. Gaya geser pada inti sambungan balok-kolom di bawah beban lateral $V_{j h}=1480,28 \mathrm{kN}$ lebih besar dari kapasitas geser sambungan $\phi C_{d n} \cos \theta=996,58 \mathrm{kN}$.

2. Tulangan geser yang dibutuhkan untuk menahan gaya geser pada inti sambungan balok-kolom di bawah beban lateral adalah sebanyak 3D12-100 mm dengan kapasitas geser sambungan $\left(\phi\left(V_{c}+V_{s}\right)+\phi C_{d n} \cos \theta\right)=1706,96 \mathrm{kN}$. Sedangkan menggunakan metode SNI 2847:2013 Pasal 21.7.4 [12] untuk hubungan balok-kolom yang terkekang di keempat sisi kolom diperoleh $\phi V_{n}=2423,26 \mathrm{kN}$ dengan tulangan geser dipasang 4D12-150 mm.

\section{Daftar Pustaka}

[1] S. E. D. E. El-Metwally and W. F. Chen, Structural concrete: Strut-and-tie models for unified design. London, New York: CRC Press Taylor \& Francis Group, 2017.

[2] S. J. Hwang and H. J. Lee, "Analytical model for predicting shear strengths of interior reinforced concrete beam-column joints for seismic resistance," ACI Structural Journal, vol. 97, no. 1, pp. 35-44, 1999.

[3] S.-J. Hwang and H.-J. Lee, "Strength Prediction for Discontinuity Regions by Softened Strut-and-Tie Model," Journal of Structural Engineering, vol. 128, no. 12, pp. 1519-1526, 2002.

[4] S. Hong and S.-G. Lee, "Strut-and-Tie Models for Deformation of Reinforced Concrete Beam-Column Joints Dependent on Plastic Hinge Behavior of Beams," in 13th World Conference on Earthquake
Engineering, 2004, vol. 1, no. 1026, pp. 1-6.

[5] H. Hwang and H. Park, "Plastic Hinge Model for Performance-Based Design of Beam-Column Joints," Journal Structure Engineering, vol. 147, no. 2, pp. 114, 2020.

[6] C. T. N. Tran and B. Li, "Analytical Model for Shearcritical Reinforced Concrete Interior Beam-column Joints," Journal of Earthquake Engineering, vol. 24, no. 8, pp. 1205-1221, 2020.

[7] L. M. Massone and G. N. Orrego, "Analytical model for shear strength estimation of reinforced concrete beam- column joints," Engineering Structures, vol. 173, no. July, pp. 681-692, 2018.

[8] V. Shobeiri, "Determination of strut-and-tie models for structural concrete under dynamic loads," Canadian Journal of Civil Engineering, vol. 46, no. 12, pp. 1090-1102, 2019.

[9] M. Pauletta et al., "Semi-empirical model for shear strength of RC interior beam-column joints subjected to cyclic loads," Engineering Structures, vol. 224, no. July, p. 111223, 2020.

[10] K. C. G. Ong, J. B. Hao, and P. Paramasivam, "A strutand-tie model for ultimate loads of precast concrete joints with loop connections in tension," Construction and Building Materials, vol. 20, pp. 169-176, 2006.

[11] Anonim, "SNI 2847:2019 Persyaratan Beton Struktural Untuk Bangunan Gedung Dan Penjelasan Sebagai Revisi Dari Standar Nasional Indonesia 2847 : 2013," no. 8, Jakarta: Badan Standardisasi Nasional, 2019, pp. 1-695.

[12] Anonim, "SNI 2847:2013 Persyaratan Beton Struktural untuk Bangunan Gedung," Jakarta: Badan Standardisasi Nasional, 2013, pp. 1-265. 